\title{
EVALUASI KESESUAIAN LAHAN PERUNTUKAN KAWASAN PERMUKIMAN, INDUSTRI, MANGROVE WILAYAH PESISIR UTARA SURABAYA TAHUN 2010 DAN 2014
}

\author{
Ayesa Pitra Andina, Muhammad Taufik \\ Jurusan Teknik Geomatika, Fakultas Teknik Sipil dan Perencanaan \\ Institut Teknologi Sepuluh Nopember (ITS) \\ Jl. Arief Rahman Hakim, Surabaya, 60111 Indonesia \\ Email : taufik_srmd @yahoo.com
}

\begin{abstract}
Abstrak
Pesisir menyediakan aksesibilitas yang lebih tinggi bagi kegiatan transportasi dan pelabuhan, serta ruang yang relatif mudah dan murah bagi kegiatan industri pergudangan, dan merupakan tempat konsentrasi penduduk yang paling padat, sekitar $75 \%$ dari total penduduk dunia bermukim di kawasan pesisir. Salah satu wilayah pesisir di Jawa Timur, yaitu pesisir utara Surabaya, mengalami dinamika perubahan cukup cepat. Surabaya sebagai pusat urban yang menunjang kegiatan sosial perekonomian wilayah Gerbangkertasusila dan sebagai pusat pengembangan ekonomi bagian timur Indonesia.
\end{abstract}

Penelitian ini mengkaji mengenai kesesuaian lahan untuk permukiman, industri, mangrove berdasarkan kondisi fisik lahan dan tingkat kesesuaian tutupan lahannya pada tahun 2010 dan 2014. Tutupan lahan diperoleh dari hasil klasifikasi digital citra ALOS AVNIR-2 dan Landsat 8. Metode analisis pada penelitian ini anatara lain reklasifikasi, overlay, scoring dan pembobotan dengan pairwise comparison, sehingga diperoleh peta kesesuaian lahan yang menggunakan basis aturan dari penelitian terdahulu.

Hasil yang diperoleh dari penelitian ini adalah diperoleh luasan tutupan lahan paling besar pada tahun 2010 adalah kelas rawa/tambak dan pada tahun 2014 kelas lahan terbuka. Hasil kesesuaian lahan dengan parameter fisik dari tiga fungsi kawasan diperoleh kelas sangat sesuai hingga sesuai marginal. Pada analisa tingkat kesesuaian eksisting permukiman di pesisir utara Surabaya dengan tipe kesesuaian sangat sesuai (S1) mengalami peningkatan sebesar $69,90 \mathrm{Ha}$, kelas indutri didominasi kelas cukup sesuai mengalami peningkatan sebesar 72,30 Ha sedangkan kelas mangrove didominasi kelas sangat sesuai dan mengalami pengurangan sebesar 4,91 $\mathrm{Ha}$ antara tahun 2010 dengan 2014

Kata Kunci : Kesesuaian Lahan, Tutupan Lahan, Permukiman, Industri, Mangrove

\section{PENDAHULUAN}

\section{Latar Belakang}

Pengembangan pelabuhan di Teluk Lamong sebagai proyek perluasan pelabuhan Tanjung Perak dan juga pembangunan kawasan perindustrian, maupun pemukiman, menyebabkan kawasan pesisir utara Surabaya menjadi sangat potensial untuk dikembangkan namun juga dapat mengancam keberadaan mangrove di pesisir utara. Maka diperlukanlah proses analisa peruntukan lahan yang tepat agar peruntukan lahan sesuai dengan kondisi fisik lahan.

Pengelolaan dan pemanfaatan sumberdaya cenderung tidak berkelanjutan, oleh karena itu perlu dilakukan kajian pengelolaan guna mencari solusi bagi pemanfaatan sumberdaya yang berkelanjutan tapi tetap menghargai karakteristik pengolahannya. Kesesuaian lahan adalah gambaran tingkat kecocokan lahan untuk tujuan peruntukan lahan tertentu dari kumpulan penentuan variabel-variabel pada kelas kesesuaian lahan yang dianalisis sebelumnya.

Karakteristik fisik sebagai faktor penting dalam melakukan analisis kesesuaian lahan dalam kaitannya dengan perencanaan pembangunan suatu wilayah sehingga diketahui sesuai tidaknya bagi peruntukan tertentu.

Berdasarkan permasalahan tersebut maka akan dikemukakan dalam penelitian ini adalah bagaimana tutupan lahan yang ada dan tingkat kesesuaian pada daerah pesisir utara Kota 
Surabaya antara tahun 2010 dan tahun 2014 berdasarkan teknik penginderaan jauh dan analisis dengan SIG. Tutupan lahan diperoleh dari hasil klasifikasi digital citra ALOS AVNIR-2 dan Landsat 8. Ketidaksesuaian pemanfaatan lahan terjadi akibat adanya konflik kepentingan antar sektor pengguna ruang dalam pemanfaatan lahan. Dilakukan analisa SIG yaitu reklasifikasi, overlay, scoring dan pembobotan dengan pairwise comparison, sehingga diperoleh peta kesesuaian lahan peruntukan permukiman, industri, dan mangrove. Dilakukan analisa kesesuaian kondisi eksisting terhadap peta tutupan lahan tahun 2010 dan 2014 dengan peta kesesuaian lahan.

\section{TINJAUAN PUSTAKA}

Salah satu pendekatan untuk membangun tata guna lahan yang tepat adalah dengan analisa kesesuaian. Penilaian kesesuaian lahan sebagai Multi Criteria Decision Making (MCDM) yang dikembangkan untuk menggabungkan faktorfaktor dalam analisa kesesuaian untuk penggunaan tertentu. Evaluasi didasarkan terhadap parameter fisik yaitu kondisi topografi, tanah, geologi, penutup lahan, maupun iklim, selain itu dapat pula mempertimbangkan aspek ekonomi dan sosial.

Analisa keputusan yang paling penting adalah penentuan nilai-nilai relatif atau bobot yang harus diberikan pada dua atau lebih faktor gabungan. Faktor-faktor tersebut berguna sebagai karakteristik lahan yang dikelompokkan sebagai atribut. Setelah faktor-faktor dipilih, faktor yang terbobot diberi nilai numerik yang menunjukkan kepentingan relatif dalam menentukan kesesuaian lahan di daerah tertentu. Kajian lahan untuk kesesuaian kawasan permukiman, industri, dan mangrove menggunakan basis aturan berdasarkan penelitian terdahulu.

\section{METODOLOGI PENELITIAN}

\section{Lokasi Penelitian}

Adapun lokasi penelitian ini adalah Kabupaten Lokasi yang digunakan pada penelitian ini adalah kawasan pesisir utara Kota Surabaya. Propinsi Jawa Timur, yang secara geografis terletak diantara $7^{\circ} 11^{\prime} 44^{\prime \prime}-7^{\circ} 14^{\prime} 43^{\prime \prime}$ LS dan $112^{\circ} 37^{\prime} 41^{\prime \prime}-112^{\circ} 45^{\prime} 41^{\prime \prime}$ BT. Berikut merupakan gambar dari lokasi penelitian :

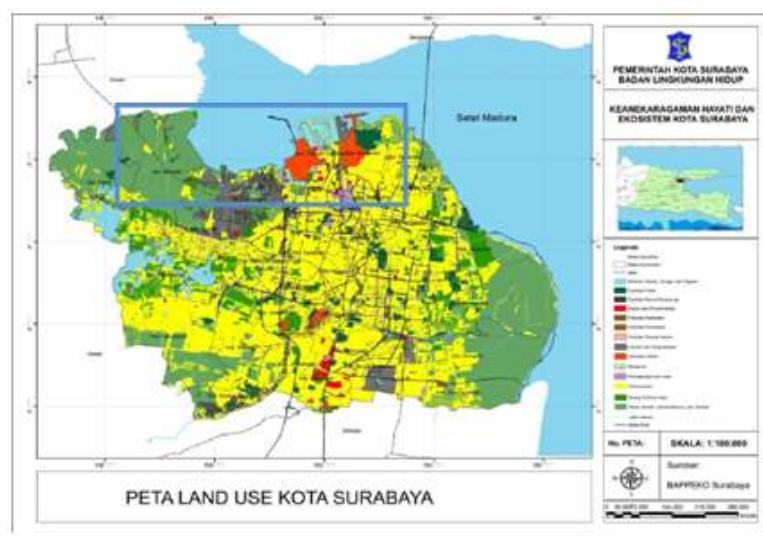

Gambar 1. Lokasi Penelitian Daerah Pesisir Utara Surabaya (Sumber: Badan Lingkungan Hidup Kota Surabaya, 2012)

\section{Tahap Pengolahan Data}

Adapun proses pengolahan data yang dilakukan ditampilkan pada diagram alir pengolahan data berikut:

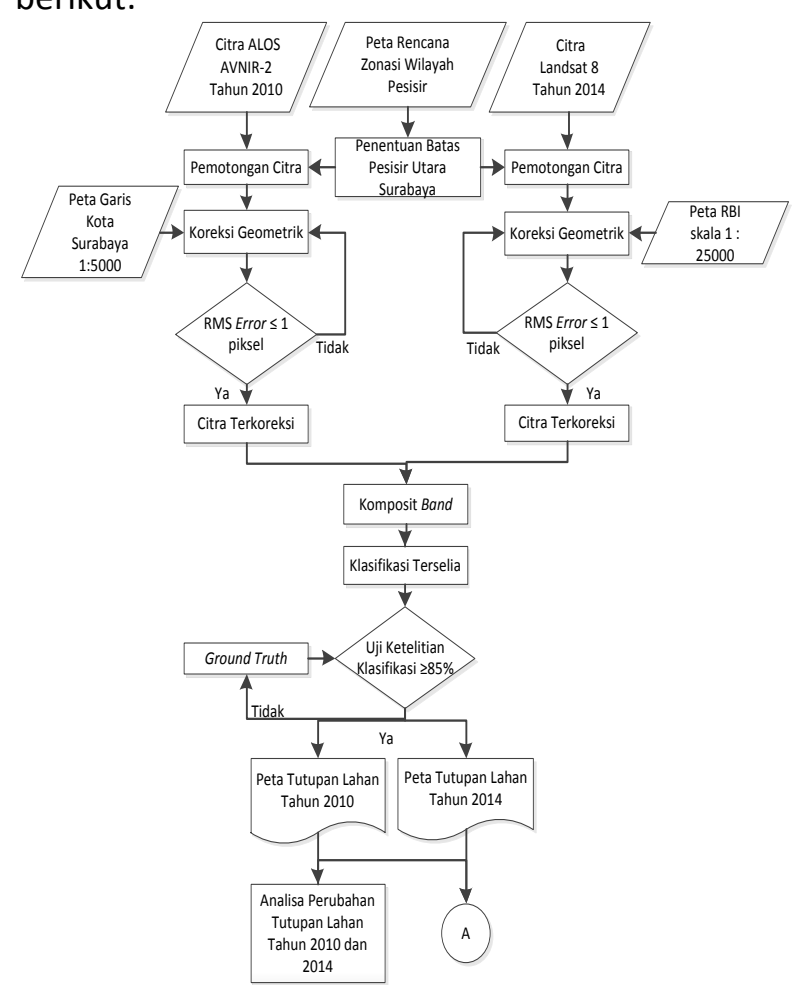

Gambar 2. Diagram Alir Pengolahan Citra.

Penjelasan dari diagram alir pengolahan data adalah sebagai berikut :

1. Pengolahan citra ALOS AVNIR-2 tahun 2010 dan Landsat 8 tahun 2014 dengan daerah studi kasus wilayah pesisir utara Kota Surabaya. Dilakukan pemotongan citra sesuai dengan daerah studi. 
2. Koreksi geometrik dilakukan agar citra hasil penginderaan jauh mempunyai sifat-sifat peta dalam bentuk, skala dan proyeksi. Menurut Purwadhi (2001), nilai RMS error harus kurang atau sama dengan 1 (RMS error $\leq 1$ piksel). Jika memenuhi toleransi maka diperoleh citra terkoreksi.

3. Peta garis Kota Surabaya dan peta RBI digunakan sebagai dasar untuk melakukan koreksi geometrik. Koreksi geometrik dilakukan dengan peletakkan titik GCP.

4. Dilakukan komposit pada citra, penggunaan jenis band yang tepat akan mempermudah tahapan interpretasi.

5. Klasifikasi dilakukan secara digital menggunakan klasifikasi terselia (terbimbing). Dilakukan identifikasi objek pada citra (training area), diklasifikasikan dengan menggunakan polygon yang mewakili daerah sampel.

6. Ground Truth digunakan untuk mendapatkan informasi keadaan tutupan lahan yang sebenarnya di lapangan.

7. Kemudian dilakukan uji ketelitian klasifikasi citra dengan perhitungan matriks kesalahan, apabila uji kebenaran $\geq 85 \%$ (Lo, 1996), maka interpretasi dianggap benar.

8. Dengan pengolahan citra digital pada ALOS AVNIR-2 dan Landsat 8, maka akan dihasilkan peta tutupan lahan tahun 2010 dan tahun 2014.

9. Dilakukan analisis perubahan tutupan lahannya dan peta tutupan lahan digunakan untuk tahapan selanjutnya.

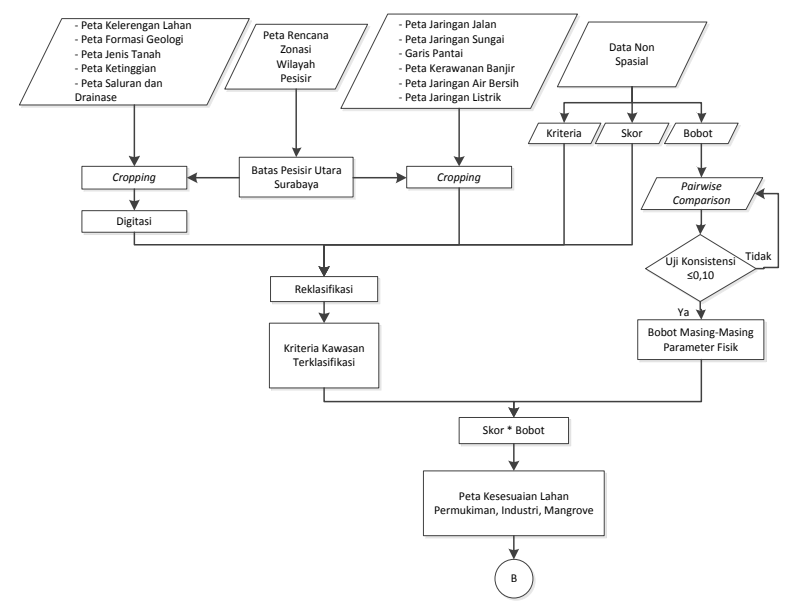

Gambar 3. Diagram Alir Kesesuaian Lahan
Penjelasan dari diagram alir pengolahan data adalah sebagai berikut:

1. Peta yang digunakan sebagai parameter fisik dalam evaluasi kesesuaian lahan dilakukan pemotongan berdasarkan rencana zonasi wilayah pesisir, dan peta dalam bentuk raster kemudian dilakukan proses digitasi.

2. Penentuan kriteria dan skor berdasarkan acuan dari basis aturan (rulebase) kesesuaian lahan permukiman, industri, dan mangrove dari penelitian terdahulu digunakan untuk reklasifikasi parameter fisik.

3. Perhitungan bobot menggunakan metode pairwise comparison dengan menentukan skala kepentingannya.

4. Dilakukan uji konsistensi, jika nilai rasio konsistensi $\leq 0,1$ bobot tiap parameter dapat digunakan untuk proses selanjutnya.

5. Dilakukan proses analisa tumpang susun (overlay) keseluruhan data yang ada, hasil skor dan bobot dari setiap parameter tersebut dijumlahkan dengan parameter yang lain, maka diperoleh peta kesesuaian lahan kawasan permukiman, industri, dan mangrove.

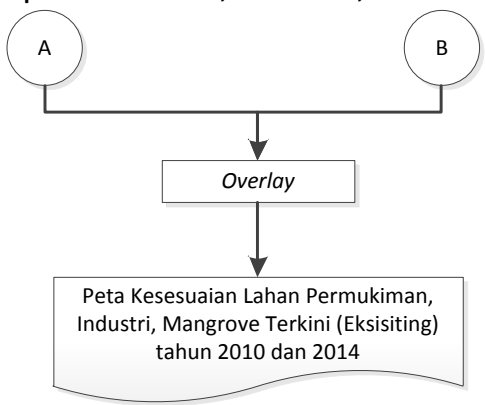

\section{Gambar 4. Diagram Alir Kesesuaian Lahan Eksisting}

Penjelasan dari diagram alir pengolahan data adalah sebagai berikut:

1. A adalah peta tutupan lahan tahun 2010 dan 2014 hasil klasifikasi citra ALOS AVNIR-2 dan Landsat 8.

2. B adalah hasil analisa kesesuaian lahan permukiman, industri dan mangrove terhadap parameter fisiknya.

Dilakukan proses overlay pada peta tutupan lahan lahan tahun 2010 dan 2014 terhadap peta kesesuaian lahan permukiman, industri dan mangrove untuk mengetahui tingkat kesesuaian kondisi eksistingnya. 


\section{HASIL DAN PEMBAHASAN}

Koreksi Geometrik dan Perhitungan Srenght of Figure (SoF) pada Citra Landsat 8

Citra ALOS AVNIR-2 dikoreksi menggunakan peta garis Kota Surabaya skala 1:5000, sedangkan untuk citra Landsat 8 dikoreksi geometrik dengan acuan peta toporafi Rupa Bumi Indonesia (RBI) skala 1:25.000 wilayah Surabaya. Dari hasil pelaksanaan koreksi geometrik menggunakan 11 titik GCP, nilai kesalahan Root Mean Square (RMS) adalah 0,20 piksel untuk citra ALOS AVNIR-2 dan 0,42 piksel pada citra Landsat 8 dengan menggunakan 12 titik GCP. Sehingga dari nilai RMS Error rata-rata yang didapatkan pada koreksi geometrik ini memenuhi syarat tersebut yaitu $\leq 1$ piksel.

Desain jaring titik-titik GCP diatas kemudian dilakukan perhitungan Srenght of Figure (SOF) sebagai berikut:

Jumlah Baseline $\quad=20$

Jumlah Titik $=11$

N Ukuran= Jumlah Baseline $\times 3=60$

$\mathrm{N}$ Parameter = Jumlah Titik $\times 3=33$

$\mathrm{U} \quad=\mathrm{N}$ Ukuran $-\mathrm{N}$ Parameter=

27

Besar SoF $\quad=\frac{\operatorname{Trace}\left(\left(A^{T} A\right)^{-1}\right)}{u}=0.15$

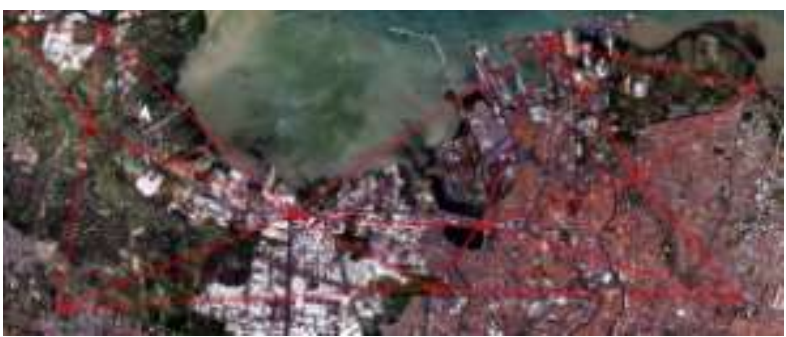

Gambar 5. Sebaran titik GCP dan desain jaring citra ALOS AVNIR-2

Nilai SoF yang dihasilkan jaring diatas telah masuk toleransi yang disyaratkan yaitu kurang dari 1, sehingga desain jaring SoF dianggap kuat.

\section{Klasifikasi Tutupan Lahan}

Klasifikasi dilakukan secara terselia (supervised) dengan algoritma maximum likelihood. Jumlah kelas yang digunakan sejumlah 7 kelas tutupan lahan. Hasil klasifikasi tutupan lahan citra ALOS tahun 2010 dan citra Landsat 8 tahun 2014 yaitu sebagai berikut:

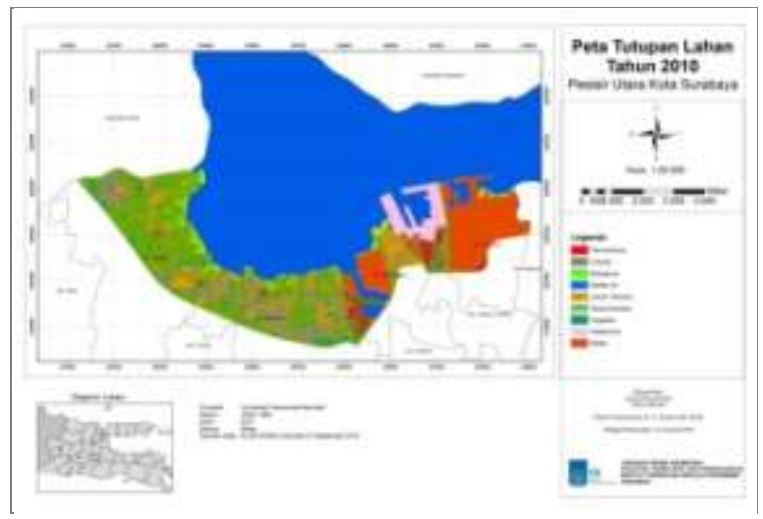

(a)

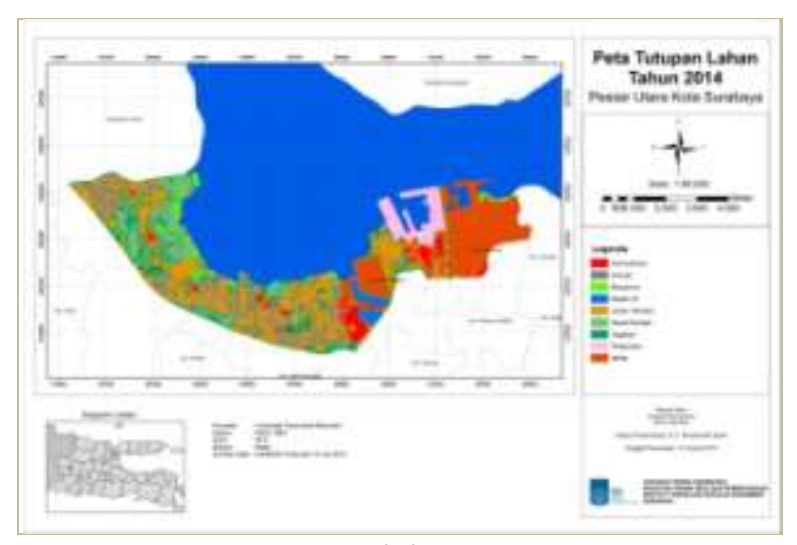

(b)

Gambar 6. (a) Hasil klasifikasi tutupan lahan tahun 2010 (b) Hasil klasifikasi tutupan lahan tahun 2014

Berikut adalah luasan hasil klasifikasi tutupan lahan citra ALOS AVNIR-2 tahun 2010 dan Landsat 8 tahun 2014:

Tabel 4. Luasan dan Persentase Perubahan Tutupan Lahan

\begin{tabular}{lccccc}
\hline $\begin{array}{l}\text { Jenis Tutupan } \\
\text { Lahan }\end{array}$ & \multicolumn{2}{c}{ Luas } & \multicolumn{2}{c}{ Luas } & Perubahan \\
& $(\mathrm{Ha})$ & $(\%)$ & $(\mathrm{Ha})$ & $(\%)$ & $(\mathrm{Ha})$ \\
\hline Permukiman & 104,75 & 4,20 & 188,32 & 7,55 & 83,57 \\
Industri & 318,19 & 12,76 & 393,23 & 15,77 & 75,04 \\
Mangrove & 92,28 & 3,70 & 71,50 & 2,87 & $-20,78$ \\
Rawa/ & 1052,21 & 42,19 & 340,11 & 13,64 & $-712,10$ \\
Tambak & & & & & \\
Badan Air & 82,26 & 3,30 & 66,69 & 2,67 & $-15,57$ \\
Lahan & 530,37 & 21,27 & 959,14 & 38,46 & 428,77 \\
Terbuka & 313,73 & 12,58 & 474,80 & 19,04 & 161,07 \\
Vegetasi & 2493,78 & 100 & 2493,78 & 100 & - \\
Total & & & & & \\
\hline
\end{tabular}




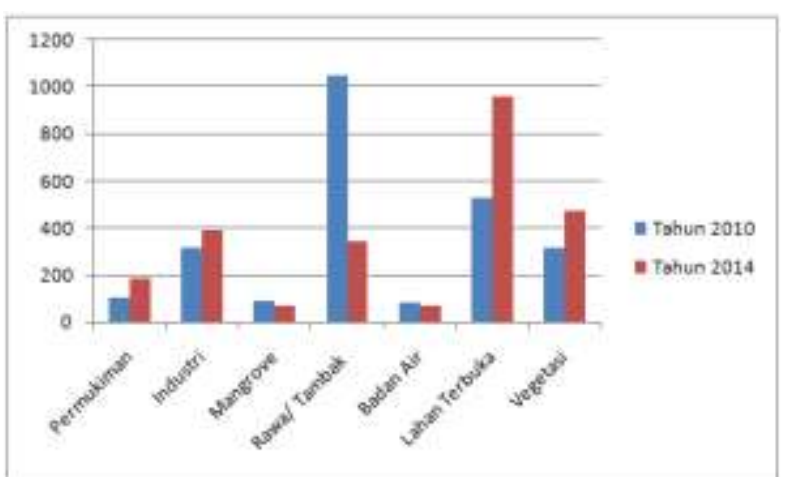

Gambar 7. Grafik Perbandingan Perubahan Tiap Jenis Tutupan Lahan Tahun 2010 dan 2014

Hasil uji ketelitian dengan mengevaluasi pola tanggapan spektral tiap kategori tutupan lahan diperoleh ketelitian keseluruhan (overall accuracy) sebesar $92,37 \%$ pada citra ALOS AVNIR-2 dan 95,35 \% pada citra Landsat 8, maka klasifikasi dianggap benar karena telah memenuhi standar nilai diatas $85 \%$.

\section{Kesesuaian Lahan Permukiman}

Analisa kesesuaian lahan permukiman dilakukan dengan teknik tumpang susun peta (overlay) dengan mengalikan bobot dari masing-masing parameter dengan skor yang diperoleh dari standar yang telah ada.

Perhitungan bobot untuk masing-masing kriteria dengan metode perbandingan berpasangan (pairwise comparison). Dilakukan dengan menentukan intensitas kepentingan. Setelah bobot diperoleh, dilakukan pengecekan konsistensi untuk matrik perbandingan berpasangannya. Karena diperoleh nilai rasio konsitensi sebesar 0,04 maka menunjukkan bahwa pembobotan masing-masing kriteria memiliki rasio yang konsisten. Diperoleh hasil pembobotan tiap parameter yaitu sebagai berikut:

Tabel 5. Bobot Kesesuaian Lahan Permukiman

\begin{tabular}{clc}
\hline No & \multicolumn{1}{c}{ Parameter } & Bobot \\
\hline 1 & Jarak dari jalan utama & 0,30 \\
2 & Jarak dari jaringan air bersih & 0,21 \\
3 & Kelerengan lahan & 0,05 \\
4 & Kerawanan Banjir & 0,20 \\
5 & Jarak dari Saluran dan Drainase & 0,24 \\
\hline
\end{tabular}

Dari hasil nilai kesesuaian lahan yang diperoleh menunjukkan bahwa semakin tinggi nilai kesesuaian lahan, maka tingkat kesesuaiannya juga semakin tinggi. Penyusunan peta kawasan dilakukan dengan cara overlay parameter fisik, maka diperoleh hasil yaitu sebagai berikut:

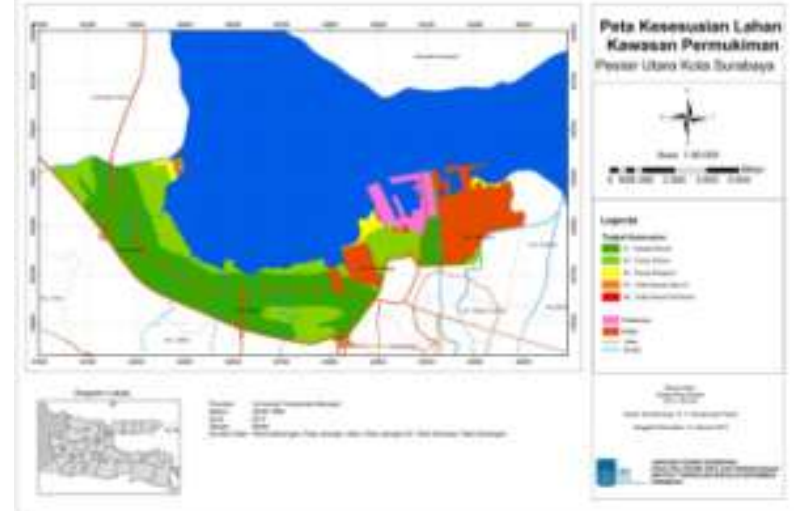

Gambar 8. Peta Kesesuaian Permukiman

\section{Kesesuaian Lahan Industri}

Dari hasil perhitungan bobot menggunakan metode pairwise comparison diperoleh rasio konsistensi sebesar 0,051, sehingga bobot dianggap konsisten. Bobot tiap parameter ditampilkan pada tabel berikut:

Tabel 6. Bobot Kesesuaian Lahan Industri

\begin{tabular}{clc}
\hline No & \multicolumn{1}{c}{ Parameter } & Bobot \\
\hline 1 & Kelerengan lahan & 0,06 \\
2 & Jarak dari jalan utama & 0,29 \\
3 & Jenis tanah & 0,07 \\
4 & Kerawanan banjir & 0,07 \\
5 & Jarak dari jaringan air bersih & 0,17 \\
6 & Jarak dari sungai & 0,09 \\
7 & Jarak dari jaringan listrik & 0,25 \\
\hline
\end{tabular}

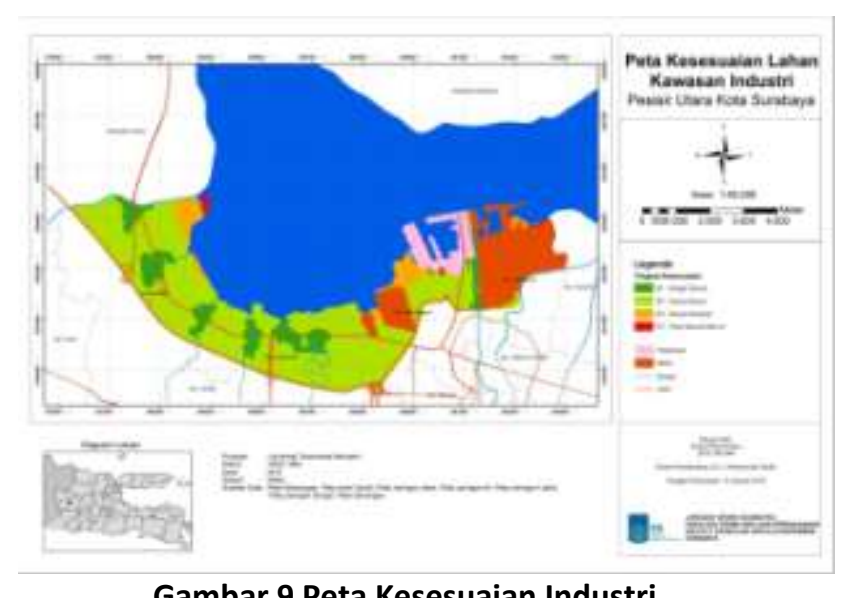

Gambar 9 Peta Kesesuaian Industri

\section{Kesesuaian Lahan Mangrove}

Nilai rasio konsistensi sebesar 0,06 , berikut merupakan hasil pembobotan masing-masing parameter kesesuaian lahan mangrove dengan pairwise comparison: 
Tabel 7. Bobot Kesesuaian Lahan Mangrove

\begin{tabular}{ccc}
\hline No & Parameter & Bobot \\
\hline 1 & Jarak dari pantai & 0,55 \\
2 & Jarak dari sungai & 0,19 \\
3 & Kelerengan lahan & 0,06 \\
4 & Ketinggian & 0,06 \\
5 & Tekstur Tanah & 0,13 \\
\hline
\end{tabular}

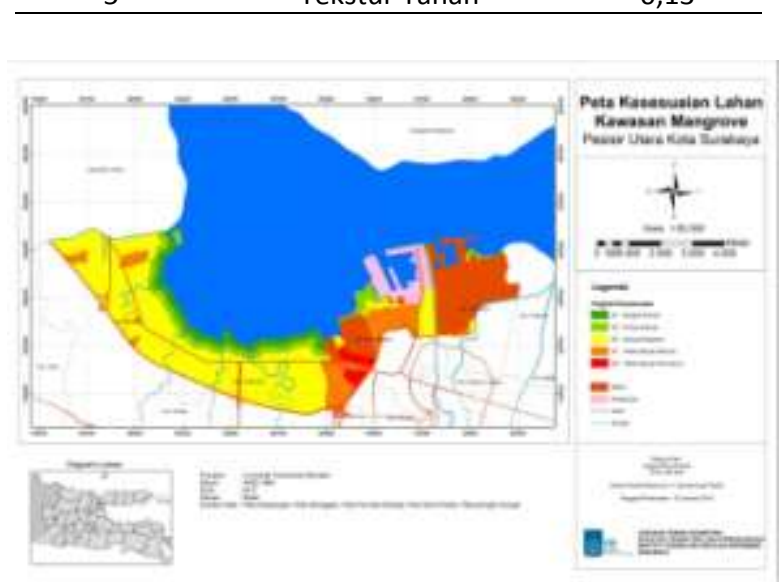

Gambar 10. Peta Kesesuaian Mangrove

\section{Kesesuaian Lahan Terkini (Eksisting)}

Analisa juga dilakukan dengan membandingkan peta kesesuaian lahan untuk permukiman, industri, dan mangrove dengan peta tutupan lahan tahun 2010 dan 2014 sehingga diketahui kesesuaian lahan terkini. Penilaian kesesuaian lahan permukiman dilakukan dengan melakukan tumpang tindih (overlay). Dari hasil analisa dapat diketahui bahwa :

Tabel 8. Perbandingan Luas Kesesuaian Lahan Eksisting Permukiman

\begin{tabular}{|c|c|c|c|c|c|c|}
\hline \multirow[b]{2}{*}{ No } & \multirow[b]{2}{*}{ Kelas } & \multirow[b]{2}{*}{ Keterangan } & \multicolumn{2}{|c|}{ Tahun 2010} & \multicolumn{2}{|c|}{ Tahun 2014} \\
\hline & & & $\begin{array}{l}\text { Luas } \\
(\mathrm{Ha})\end{array}$ & $\begin{array}{c}\text { Luas } \\
(\%)\end{array}$ & $\begin{array}{l}\text { Luas } \\
(\mathrm{Ha})\end{array}$ & $\begin{array}{c}\text { Luas } \\
(\%)\end{array}$ \\
\hline 1 & S1 & Sangat Sesuai & 70,48 & 67,28 & 140,38 & 74,54 \\
\hline 2 & S2 & Cukup Sesuai & 34,20 & 32,65 & 47,77 & 25,37 \\
\hline 3 & S3 & $\begin{array}{c}\text { Sesuai } \\
\text { Bersyarat }\end{array}$ & 0,07 & 0,07 & 0,17 & 0,09 \\
\hline \multicolumn{3}{|c|}{ Total } & 104,75 & 100 & 188,32 & 100 \\
\hline
\end{tabular}

Tabel 9. Perbandingan Luas Kesesuaian Lahan Eksisting Industri

\begin{tabular}{|c|c|c|c|c|c|c|}
\hline \multirow[b]{2}{*}{ No } & \multirow[b]{2}{*}{ Kelas } & \multirow[b]{2}{*}{ Keterangan } & \multicolumn{2}{|c|}{ Tahun 2010} & \multicolumn{2}{|c|}{ Tahun 2014} \\
\hline & & & $\begin{array}{l}\text { Luas } \\
(\mathrm{Ha})\end{array}$ & $\begin{array}{c}\text { Luas } \\
(\%)\end{array}$ & $\begin{array}{l}\text { Luas } \\
(\mathrm{Ha})\end{array}$ & $\begin{array}{c}\text { Luas } \\
(\%)\end{array}$ \\
\hline 1 & S1 & $\begin{array}{l}\text { Sangat } \\
\text { Sesuai }\end{array}$ & 34,43 & 10,82 & 39,76 & 10,11 \\
\hline 2 & S2 & $\begin{array}{l}\text { Cukup } \\
\text { Sesuai }\end{array}$ & 280,23 & 88,07 & 352,53 & 89,65 \\
\hline 3 & S3 & $\begin{array}{c}\text { Sesuai } \\
\text { Bersyarat }\end{array}$ & 3,53 & 1,11 & 0,94 & 0,24 \\
\hline \multicolumn{3}{|c|}{ Total } & 318,19 & 100 & 393,23 & 100 \\
\hline
\end{tabular}

Tabel 10. Perbandingan Luas Kesesuaian Lahan Eksisting Mangrove

\begin{tabular}{ccccccc}
\hline \multirow{2}{*}{ No } & Kelas & & \multicolumn{2}{c}{ Tahun 2010} & \multicolumn{2}{c}{ Tahun 2014 } \\
& & Luas & Luas & \multicolumn{2}{c}{ Luas } & Luas \\
$(\mathrm{Ha})$ & $(\mathrm{Ha})$ & $(\%)$ \\
\hline 1 & S1 & $\begin{array}{c}\text { Sangat } \\
\text { Sesuai }\end{array}$ & 41,96 & 45,47 & 37,05 & 51,82 \\
2 & S2 & $\begin{array}{c}\text { Cukup } \\
\text { Sesuai }\end{array}$ & 40,38 & 43,76 & 26,24 & 36,71 \\
3 & S3 & $\begin{array}{c}\text { Sesuai } \\
\text { Bersyarat }\end{array}$ & 9,94 & 10,77 & 8,20 & 11,47 \\
& \multicolumn{2}{c}{ Total } & 92,28 & 100 & 71,50 & 100 \\
\hline
\end{tabular}

\section{KESIMPULAN DAN SARAN}

Berdasarkan hasil penelitian, dapat diperoleh kesimpulan antara lain sebagai berikut:

1. Diperoleh kelas tutupan lahan permukiman, industri, mangrove, daerah bervegetasi, lahan terbuka, rawa/tambak, tubuh air. Pada tahun 2010 didominasi oleh kelas rawa/tambak, sedangkan pada tahun 2014 didominasi oleh kelas lahan terbuka.

2. Hasil kesesuaian lahan peruntukan permukiman berdasarkan parameter fisik diperoleh kelas kesesuaian sangat sesuai sebesar 1607,83 Ha (64,47\%), kesesuaian untuk peruntukan industri paling besar adalah kelas cukup sesuai yaitu 1958,41 Ha (78,53\%), sedangkan pada kelas kesesuaian mangrove luasan paling besar pada kelas sesuai bersyarat sebesar $1619,03 \mathrm{Ha}(64,92 \%)$.

3. Analisa kesesuaian eksisting menunjukkan bahwa keadaan eksisting kawasan permukiman memiliki kesesuaian yang tinggi yaitu kelas sangat sesuai, mengalami peningkatan kesesuaian sebesar 69,90 $\mathrm{Ha}$. Untuk hasil kesesuaian kondisi eksisting industri paling besar adalah kelas kesesuaian cukup sesuai yang mengalami peningkatan sebesar 72,30 Ha antara tahun 2010 dan 2014. Sedangkan berdasarkan hasil evaluasi kesesuaian lahan mangrove diperoleh luasan paling besar pada kelas sangat sesuai, dan mengalami pengurangan luasan sebesar 4,91 Ha.

\section{DAFTAR PUSTAKA}

Yudonyono, A., Hasyim, A.W., Andriyono, S. (2010). Perencanaan Wilayah Berupa Pengembangan Silvofishery Mengacu PERMEN LH No.17 Tahun 2009 dengan Aplikasi Sistem Informasi Geografis 
dan Penginderaan Jauh. Makalah disajikan pada Seminar Nasional FTSP ITN. Malang. 15 Juli 2010.

Boonyanuphap, J. (2004). GIS- Based Land Suitability Assessment for Musa (ABB Group) Plantation. Jepang: Ehime University.

Setyowati. (2004). Laporan Penelitian Aplikasi Sistem Informasi Geografis untuk Mitigasi Rawan Bencana Pada Wilayah Pengembangan Permukiman di Kota Semarang. Semarang: Lembaga Penelitian UNNES.

Hudayana, A. (2005). Evaluasi Kesesuaian Lahan untuk Permukiman di Kota Surabaya Menggunakan Metode Simple Additive Weighting (SAW) Berbasis Sistem Informasi Geografis. Surabaya: ITS.

Tim Penyusun Kesesuaian Lahan. (1994). Kursus Evaluasi Sumberdaya Lahan. Yogyakarta: Fakultas Geografi UGM.

Kaiser, E. et.al. (1995). Urban Land Use Planning. Fouth Edition. Urbana and Chicago: University of Illinois Press.

Charungthanakij, S. (2007), Land Suitability Assesment for Industrial Location Development Using MCDA). Thailand: Suranaree University of Technology.

Dai, L. (2008). Evaluating Land-Use Suitability of an Industrial City in Northeast China. China: Chines Academy of Sciences.

Aminudin (2003). Analisis Pemanfaatan Ruang Kawasan Pesisir Teluk Lampung di Propinsi Lampung. Yogyakarta: UGM.

Wardhani, M. (2011). Analisis Keberlanjutan Kawasan Potensi Wisata Pantai di Pesisir Selatan Kabupaten Bangkalan. Bogor: Sekolah Pascasarjana Institut Pertanian Bogor 


\section{LAMPIRAN}

Tabel 1. Kriteria Lahan untuk Kawasan Pemukiman

\begin{tabular}{|c|c|c|c|c|c|c|c|c|c|c|}
\hline Parameter & Kategori & Skor & Kategori & Skor & Kategori & Skor & Kategori & Skor & Kategori & Skor \\
\hline $\begin{array}{l}\text { Jarak dari } \\
\text { prasarana } \\
\text { jalan }(\mathrm{m})\end{array}$ & $<500$ & 5 & $500-1000$ & 4 & $1001-1500$ & 3 & $1501-2000$ & 2 & $>2000$ & 1 \\
\hline $\begin{array}{l}\text { Jarak dari } \\
\text { Jaringan Air } \\
\text { Bersih (m) }\end{array}$ & $<500$ & 5 & $500-1000$ & 4 & $1001-1500$ & 3 & $1501-2000$ & 2 & $>2000$ & 1 \\
\hline $\begin{array}{l}\text { Kelerengan } \\
\text { Lahan (\%) }\end{array}$ & $0-2$ & 5 & $3-8$ & 4 & $9-30$ & 3 & $31-45$ & 2 & $>45$ & 1 \\
\hline $\begin{array}{l}\text { Kerawanan } \\
\text { Banjir }\end{array}$ & $\begin{array}{l}\text { Tidak pernah } \\
\text { tergenang }\end{array}$ & 5 & $<2$ jam & 4 & 2-4 jam & 3 & 4-6 jam & 2 & $>6$ jam & 1 \\
\hline $\begin{array}{l}\text { Jarak dari } \\
\text { Saluran dan } \\
\text { Drainase }\end{array}$ & $<500$ & 5 & $500-1000$ & 4 & $1001-1500$ & 3 & $1501-2000$ & 2 & $>2000$ & 1 \\
\hline
\end{tabular}

Tabel 2. Kriteria Lahan untuk Kawasan Industri

\begin{tabular}{|c|c|c|c|c|c|c|c|c|c|c|}
\hline Parameter & Kategori & Skor & Kategori & Skor & Kategori & Skor & Kategori & Skor & Kategori & Skor \\
\hline $\begin{array}{l}\text { Kelerengan } \\
\text { lahan (\%) }\end{array}$ & $0-2$ & 5 & $3-15$ & 4 & $16-25$ & 3 & $26-40$ & 2 & $>40$ & 1 \\
\hline $\begin{array}{l}\text { Jarak dari } \\
\text { prasarana } \\
\text { jalan }(\mathrm{m})\end{array}$ & $<500$ & 5 & $500-1000$ & 4 & $1001-1500$ & 3 & $1501-2000$ & 2 & $>2000$ & 1 \\
\hline Jenis Tanah & $\begin{array}{l}\text { Alluvial } \\
\text { Hidromorf, } \\
\text { Alluvial Kelabu, } \\
\text { Glay, Planosol, } \\
\text { Literit Air } \\
\text { Tanah }\end{array}$ & 5 & Latosol & 4 & $\begin{array}{l}\text { Brown Forest, Non } \\
\text { Caltic Brown, } \\
\text { Mediterania }\end{array}$ & 3 & $\begin{array}{l}\text { Andesol, } \\
\text { Lateric, } \\
\text { Grumosol, } \\
\text { Podsol, } \\
\text { Podsoltic }\end{array}$ & 2 & $\begin{array}{l}\text { Regosol, Litosol, } \\
\text { Organosol, } \\
\text { Renzina }\end{array}$ & 1 \\
\hline $\begin{array}{l}\text { Kerawanan } \\
\text { Banjir }\end{array}$ & $\begin{array}{l}\text { Tidak pernah } \\
\text { tergenang }\end{array}$ & 5 & $\begin{array}{l}\text { Hampir tidak } \\
\text { terjadi genangan } \\
\text { dalam } 1 \text { tahun, jika } \\
\text { terjadi genangan } \\
<1 \text { jam. }\end{array}$ & 4 & $\begin{array}{l}\geq 3 \text { kali tergenang } \\
\text { dalam satu tahun, } \\
\text { genangan 3-5 jam. }\end{array}$ & 3 & $\begin{array}{l}\geq 5 \text { kali } \\
\text { tergenang } \\
\text { dalam satu } \\
\text { tahun. }\end{array}$ & 2 & Selalu tergenang & 1 \\
\hline $\begin{array}{l}\text { Jarak dari } \\
\text { Jaringan Air } \\
\text { Bersih (m) } \\
\text { (feet) }\end{array}$ & $<500$ & 5 & $500-2640$ & 4 & $2641-5280$ & 3 & $>5280$ & 2 & - & - \\
\hline $\begin{array}{l}\text { Jarak dari } \\
\text { Sungai }(\mathrm{m})\end{array}$ & $<60$ & 5 & $60-120$ & 4 & $121-180$ & 3 & $181-240$ & 2 & $>240$ & 1 \\
\hline $\begin{array}{l}\text { Jarak dari } \\
\text { Aliran Listrik } \\
\text { (m) }\end{array}$ & $0-500$ & 5 & $501-1000$ & 4 & $1001-1500$ & 3 & $1501-2000$ & 2 & $>2000$ & 1 \\
\hline
\end{tabular}

(Sumber: Tim Penyusun Kesesuaian Lahan (1994) dengan modifikasi, Keiser et al, (1995), Charungthanakij (2007), dan Dai (2008))

Tabel 3. Kriteria Lahan untuk Kawasan Mangrove

\begin{tabular}{|c|c|c|c|c|c|c|c|c|c|c|}
\hline Parameter & Kategori & Skor & Kategori & Skor & Kategori & Skor & Kategori & Skor & Kategori & Skor \\
\hline $\begin{array}{l}\text { Kelerengan } \\
\text { lahan (\%) }\end{array}$ & $0-2$ & 5 & $3-5$ & 4 & $6-8$ & 3 & $9-15$ & 2 & $>15$ & 1 \\
\hline $\begin{array}{l}\text { Jarak dari Garis } \\
\text { Pantai (m) }\end{array}$ & $<200$ & 5 & $200-300$ & 4 & $300-400$ & 3 & $400-500$ & 2 & $>500$ & 1 \\
\hline $\begin{array}{l}\text { Jarak dari } \\
\text { Sungai (m) }\end{array}$ & $<500$ & 5 & $500-1000$ & 4 & $1001-1500$ & 3 & 1501- 2000 & 2 & $>2000$ & 1 \\
\hline Tekstur Tanah & Silty Clay & 5 & Sandy Clay & 4 & Loam Sand & 3 & - & - & - & - \\
\hline
\end{tabular}

(Sumber: Aminudin, (2003) dengan modifikasl, Wardhani, (2011)) 